\title{
Caffeoyl Derivatives: Major Antioxidant Compounds of Some Wild Herbs of the Asteraceae Family
}

\author{
Didier Fraisse, Catherine Felgines, Odile Texier, Jean-Louis Lamaison
}

Laboratoire de Pharmacognosie et Phytothérapie, Clermont-Ferrand, France.

Email: catherine.felgines@u-clermont1.fr

Received February $28^{\text {th }}, 2011$; Revised March 28 ${ }^{\text {th }}, 2011$; Accepted April $28^{\text {th }}, 2011$.

\begin{abstract}
The polyphenolic composition and antioxidant activity of the aerial parts of 18 medicinal or food plants of the Asteraceae family were studied. Five main caffeoyl derivatives were determined individually by HPLC and compared with levels determined by colorimetry for total dihydroxycinnamic derivatives and total phenolics. The aim of this study was to assess the contribution of these constituents to the antioxidant activity of the herbs determined by DPPH radical scavenging tests. Significant correlations were found between total phenolic $\left(R^{2}=0.8904\right)$, total dihydroxycinnamic derivative $\left(R^{2}=0.8529\right)$ and total caffeoyl derivative $\left(R^{2}=0.7172\right)$ concentrations and the DPPH-scavenging ability of all herbs. The antioxidant activity of the main constituents, including chicoric acid $\left(E C_{50}=8.24 \mu \mathrm{mol} / \mathrm{l}\right)$ or 3,5 dicaffeoylquinic acid $\left(E C_{50}=7.62 \mu \mathrm{mol} / \mathrm{l}\right)$, was very high compared to vitamin $C\left(E C_{50}=15.66 \mu \mathrm{mol} / \mathrm{l}\right)$. Thus, for each species, antioxidant activity mainly involves the major caffeoyl derivatives. The contribution to antioxidant activity were assessed as $48.92 \%$ for 3,5-dicaffeoylquinic acid in Tanacetum parthenium $(30.08 \mathrm{~g} / \mathrm{kg})$, and $68.96 \%$ for chicoric acid in Taraxacum officinale (34.08 $\mathrm{g} / \mathrm{kg}$ ). The main caffeoyl derivatives among polyphenols can be considered as the major antioxidant compounds of the studied Asteraceae herbs.
\end{abstract}

Keywords: Plants, Asteraceae, Caffeoyl Derivatives, Antioxidant

\section{Introduction}

Polyphenols, particularly flavonoids, have attracted a great deal of research on their broad distribution in plants, their physiological (including antioxidant) activities, and their health effects [1-3]. In the Asteraceae family, flavonoid composition has long been established, but much less is known about their phenolic acid derivatives composition. The most common flavonoids are the 7-glycosides of apigenin and luteolin $[4,5]$. Among the dihydroxycinnamic derivatives, the oldest known are cynarin (dicaffeoylquinic acid) from artichoke and chicoric acid (dicaffeoyltartaric acid) from chicory [6,7]. Among the 18 medicinal or food species of Asteraceae studied, recent work has helped clarify the caffeoylquinic acid composition or show the presence of these constituents in some of these plants. In the subfamily Cichorioideae, chicory and dandelion leaves but not mouse-ear contain large amounts of chicoric acid [8-10]. In the subfamily
Asterideae, the dicaffeoylquinic acid composition is now relatively well known for arnica, chamomiles, feverfew, giant goldenrod, milfoil, mugwort and tansy, but these compounds have not been revealed in the other plants studied [11-19]. Extensive research on the antioxidant activity of plants was performed in the Asteraceae family [20-32]. In some cases, antioxidant capacity was related to the presence of polyphenols, including favonoids [33-41]. To our knowledge, only two studies highlighted important roles of dicaffeoylquinic derivatives in antioxidant activity, one in feverfew and the other in tansy $[15,19]$.

Having previously reported that the major polyphenols in aerial parts of mugwort and yarrow were dicaffeoylquinic acids $[17,18]$, we screened and assayed these constituents in other Asteraceae herbs and studied whether they had an impact on the antioxidant activity of these plants. The aim of this study was to specify the qualitative and quantitative composition of five main caffeoyl 
derivatives, i.e. chlorogenic acid, chicoric acid and 1,5-, 3,5- and 4,5-di-O-caffeoylquinic acids in the aerial parts of 18 wild plants of European Asteraceae used in traditional medicine or food. In addition to dihydroxycinnamic derivatives, we ran comparative assays on the overall content of flavonoids and phenolics that also demonstrate marked antioxidant activity. We then investigated the correlation between total antioxidant capacity, determined in vitro using the 2,2'-diphenyl1-picrylhydrazyl free radical (DPPH) assay, of each plant and their main antioxidant polyphenolic compounds.

\section{Materials and Methods}

\subsection{Plant Material}

Aerial parts, i.e. flowering tops or leaves (if specified), of 18 medicinal or food taxa of the Asteraceae (or Compositae) family were examined, i.e. Achillea millefolium subsp. millefolium, Arnica montana subsp. montana, Artemisia absinthium, Artemisia verlotiorum, Artemisia vulgaris, Calendula officinalis, Chamaemelum nobile, Chamomilla recutita, Cichorium intybus (leaves), Conyza canadensis, Eupatorium cannabinum subsp. cannabinum, Hieracium pilosella s.l., Matricaria perforata, Solidago gigantea subsp. serotina, Solidago virgaurea subsp. virgaurea, Tanacetum parthenium, Tanacetum vulgare, Taraxacum officinale gr. (leaves). Samples of each herb were collected wild at flowering in the Auvergne (France) in summer 2005. All plants were identified and named using Flora Europaea [42].

\subsection{Chemicals}

Standard chlorogenic acid was purchased from Extrasynthese (Genay, France). Chicoric acid (dicaffeoyltartaric acid) and 1,5-, 3,5- and 4,5-di-O-caffeoylquinic acids were isolated as described elsewhere [7,15,18]. All other reagents were of pharmacopoeia purity and organic solvents were HPLC grade (Merck, Darmstadt, Germany).

\subsection{Polyphenolic Compound Extraction Procedure}

Samples of herbs desiccated in the lab at room temperature were pulverized in a laboratory crusher (IKA A10 type, Bioblock, Illkirch, France). The powder was sieved (mesh $0.5 \mathrm{~mm}$ ) and $250 \mathrm{mg}$ of ground sample were carefully extracted with $100 \mathrm{ml}$ of $\mathrm{EtOH} / \mathrm{H}_{2} \mathrm{O}(50: 50 \mathrm{v} / \mathrm{v})$ in a water bath at $80^{\circ} \mathrm{C}$ for $1 \mathrm{~min}$, stirred for $1 \mathrm{~h}$ at room temperature, then filtered. Before HPLC analysis, the samples were filtered through a $0.45 \mu \mathrm{m}$ filter (Acrodisc GPH, Gelman, Ann Arbor, MI, USA).

\subsection{TLC Identification of Caffeoyl Derivatives}

Qualitative analysis of polyphenols by TLC was carried out with a routine technique using Silicagel $60 \mathrm{~F}_{254}$ plates (Merck) [43]. The mobile phase was: toluene/ethyl formate/water/formic acid (10:100:5:10 v/v). A $10 \mu 1$ aliquot of each sample solution prepared as above and $10 \mu \mathrm{l}$ of each selected standard solution $(0.5 \mathrm{mg} / \mathrm{ml})$ were applied comparatively on the layer. After migration then drying, Neu reagent was sprayed on the plate. Neu reagent was previously prepared with $10 \mathrm{ml}$ of $1 \%$ methanolic diphenylboric acid 2-aminoethyl ester (Fluka) and 8 $\mathrm{ml}$ of 5\% ethanolic polyethylene glycol 4000 (Sigma, St Louis, MO, USA). After $1 \mathrm{~h}$ at room temperature, each standard compound studied under UV light at $365 \mathrm{~nm}$ appeared with blue fluorescence at frontal ratio $(R f)$ : chlorogenic acid (0.20), 4,5-di-O-caffeoylquinic acid (0.43), 1,5-di-O-caffeoylquinic acid (0.62), 3,5-di-O-caffeoylquinic acid $(0.65)$, chicoric acid $(0,66)$.

\subsection{HPLC Analysis of Caffeoyl Derivatives}

Qualitative and quantitative HPLC analysis was carried out with an apparatus comprising two 510 pumps, a 680 solvent programmer and a 991 photodiode array detector (Waters Associates, Milford, MA, USA). A $25 \mu 1$ aliquot was injected onto a Lichrocart 125-4 Superspher RP8-E $5 \mu \mathrm{m}$ column (Merck). The mobile phase consisted of solvent $\mathrm{A}: \mathrm{H}_{2} \mathrm{O} / \mathrm{H}_{3} \mathrm{PO}_{4} 85 \%(100: 0.3 \mathrm{v} / \mathrm{v})$ and solvent $\mathrm{B}$ : $\mathrm{MeCN} / \mathrm{H}_{2} \mathrm{O} / \mathrm{H}_{3} \mathrm{PO}_{4} 85 \%$ (80:20:0.3 v/v). Separation was performed by a quadriconcave gradient of $\mathrm{B}$ in $\mathrm{A}$ at a flow rate of $2 \mathrm{ml} / \mathrm{min}$ as follows: $0-5 \mathrm{~min}, 12 \%-15 \% \mathrm{~B}$; 5 - $30 \mathrm{~min}, 15 \%$ - $30 \% \mathrm{~B}$; 30 - $40 \mathrm{~min}, 30 \%$ - 50\% B; 40 $45 \mathrm{~min}, 50 \%-70 \% \mathrm{~B}$. Under these conditions, standard compounds were correctly separated and eluted at approximate retention times $\left(R_{t}\right)$, as follows: chlorogenic acid (7.1 min), 3,5-di-O-caffeoylquinic acid (32.5 min), 1,5-di-O-caffeoylquinic acid (33.0 $\mathrm{min})$, chicoric acid (33.5 min), 4,5-di-O-caffeoylquinic acid (34.2 $\mathrm{min})$. The specificity of the method was verified for each hydroxycinnamic constituent using a photodiode array detector to compare their UV spectra with those of standard compounds. UV absorption maxima were 217, 238 and 325 $\mathrm{nm}$ for chlorogenic acid, 218, 241 and 328 for 3,5-di-Ocaffeoylquinic acid, 218, 240 and 328 for 1,5-di-O-caffeoylquinic acid, 218, 243 and 329 for chicoric acid and 217, 241 and 326 for 4,5-di-O-caffeoylquinic acid. Detection was therefore carried out at $340 \mathrm{~nm}$ for all compounds. Linearity and reliability standard deviations of caffeoyl derivatives were $<5 \%$. Linearity correlation coefficient was greater than 0.99 (5 points; 3 assays). All samples were run in triplicate and quantification was carried out using external standards. The content of each compound was calculated and expressed as $\mathrm{g} / \mathrm{kg}$ on dry 
matter (DM) [17].

\subsection{Determination of Total Dihydroxycinnamic Derivatives}

Total dihydroxycinnamic acid contents (including caffeoyl derivatives) were expressed as chlorogenic acid as previously described in the European Pharmacopoeia (6th ed. 2008) for Fraxini folium [44]. The extract (1 ml) was added to $2 \mathrm{ml} 0.5 \mathrm{M} \mathrm{HCl}, 2 \mathrm{ml}$ Arnow's reagent $(10 \mathrm{~g}$ sodium nitrite and $10 \mathrm{~g}$ sodium molybdate made up to $100 \mathrm{ml}$ with distilled water), $2 \mathrm{ml} \mathrm{NaOH}$ (at a concentration of $2.125 \mathrm{M}$ ) and $3 \mathrm{ml}$ of water. Each solution was compared with the same mixture without Arnow's reagent. Absorbance was read at $525 \mathrm{~nm}$. The content of each plant was calculated and expressed as g/kg DM.

\subsection{Determination of Total Flavonoids}

Total flavonoid contents were determined and expressed as luteolin 7-glucoside as previously described in the European Pharmacopoeia (6th ed. 2008) for Passiflorae herba [44]. The extract $(1 \mathrm{ml})$ was evaporated to dryness under reduced pressure, and the residue dissolved in 10 $\mathrm{ml}$ of $\mathrm{MeOH} /$ acetic acid (10:100 v/v). The solution was added to $10 \mathrm{ml}$ oxaloboric reagent $(25 \mathrm{~g}$ boric acid and $20 \mathrm{~g}$ sodium molybdate made up to $1000 \mathrm{ml}$ with anhydrous formic acid) and adjusted to $25 \mathrm{ml}$ with anhydrous acetic acid. Each solution was compared with the same mixture without reagent. After $30 \mathrm{~min}$, absorbance was read at $401 \mathrm{~nm}$. The content of each plant was calculated and expressed as $\mathrm{g} / \mathrm{kg} \mathrm{DM}$.

\subsection{Determination of Total Polyphenolic Compounds}

The amount of total phenolics was determined according to the Folin-Ciocalteu procedure [45]. The Folin reagent (diluted 1:10 in water, $750 \mu \mathrm{l})$ and aqueous $\mathrm{Na}_{2} \mathrm{CO}_{3}(75$ $\mathrm{g} / \mathrm{l}, 600 \mu \mathrm{l})$ were successively added to the herb extract $(150 \mu \mathrm{l})$. The mixture was kept in a water bath at $50^{\circ} \mathrm{C}$ for $5 \mathrm{~min}$, then chilled on ice before reading absorbance at $760 \mathrm{~nm}$. Pyrogallol was used to establish the calibration curve, and total polyphenolic content was expressed as $\mathrm{g} / \mathrm{kg} \mathrm{DM}$.

\subsection{Determination of Antioxidant Activity}

Extraction was carried out using $250 \mathrm{mg}(\mathrm{m})$ of plant powder in $100 \mathrm{ml}$ of $\mathrm{EtOH} / \mathrm{H}_{2} \mathrm{O}(50: 50 \mathrm{v} / \mathrm{v})$. The mixture was carefully heated for $1 \mathrm{~min}$ in a water bath at $80^{\circ} \mathrm{C}$, then stirred for $1 \mathrm{~h}$ at room temperature and filtered. The absorbance of a blank $(2.5 \mathrm{ml}$ of $25 \mathrm{mg} / 1 \mathrm{DPPH}$ (colored radical) in $\mathrm{MeOH}+10 \mu \mathrm{l}$ of $\left.\mathrm{EtOH} / \mathrm{H}_{2} \mathrm{O}(50: 50 \mathrm{v} / \mathrm{v})\right)$ was compared with the absorbance of the sample extract $(2.5$ $\mathrm{ml}$ of $25 \mathrm{mg} / \mathrm{lDPPH}$ in $\mathrm{MeOH}+10 \mu \mathrm{l}$ of extractive solution). After $30 \mathrm{~min}$, absorbance (A) was determined at
$517 \mathrm{~nm}$ [46].

Relative antioxidant activity on DPPH (total capacity \%) was expressed as a percentage decrease of the absorbance of origin $\left(A_{0}\right)$ :

$$
\text { Total Capacity } \%=\left(A_{0}-A\right) \times 100 / A_{0}
$$

Absolute antioxidant activity was expressed as the amount of plant yielding a $50 \%$ decrease in the original color under the test conditions, so that half maximal effective concentration $\left(\mathrm{EC}_{50}\right)$ in $\mu \mathrm{g}$ of plant by $\mathrm{ml}$ of reaction mixture was given by:

$$
\begin{aligned}
\mathrm{EC}_{50} & =m \times 50 \times 10 / 2.5 \times 100 \times(\text { total capacity } \%) \\
& =m \times 2 /(\text { total capacity } \%)
\end{aligned}
$$

For the compounds isolated, $\mathrm{EC}_{50}$ were expressed in $\mu \mathrm{mol} / 1$.

\subsection{Calculation of the Contribution of Caffeoyl Derivatives to Total Antioxidant Activity}

After determining the amount of each caffeoyl derivative by HPLC, their contribution to the total antioxidant capacity (\%) of each plant was calculated as described previously for chicoric acid (dicaffeoyltartaric acid) and chlorogenic acid [47].

" $A$ " was the amount of chicoric acid determined by HPLC (g/kg DM). First, we calculated the amount of chicoric acid in $10 \mu$ l of extraction solution:

$$
A \times m \times 10 / 1000 \times 100
$$

The antioxidant activity of chicoric acid solution used as reference $\left(A_{0}\right.$ : amount of chicoric acid expressed as $\mathrm{mg} / \mathrm{ml}$ ) was $34.44 \%$.

Then, the percentage activity due to chicoric acid from plant was calculated as:

$$
X \%=A \times m \times 10 \times 34.44 / A_{0} \times 1000 \times 100 \times 10
$$

The contribution of chicoric acid to the total antioxidant capacity of each plant was calculated as:

$$
X \% \times 100 /(\text { total capacity } \%)
$$

The same method was applied to determine the contributions of chlorogenic acid and 1,5-, 3,5-, and 4,5- dicaffeoylquinic acids.

\subsection{Statistical Analysis}

Results of triplicate analyses were expressed as mean \pm SD. Relationships between phenolic compound contents and antiradical efficiency were established using the Pearson correlation test $(P<0.05)$.

\section{Results and Discussion}

\subsection{Polyphenolic Composition of the $\mathbf{1 8}$ Asteraceae Herbs}

In the 18 Asteraceae samples, 5 major caffeoyl derivatives 
were individually investigated. Each component was cochromatographed (TLC and HPLC) with its corresponding standard substance, and the spectral characteristics were compared for identification. Ubiquitous chlorogenic acid (3-caffeoylquinic acid) was present in all herbs, confirming previous results [17]. Chicoric acid (dicaffeoyltartaric acid) was present only in two studied species of the subfamily Cichorioideae, i.e. C. intybus and T. officinale, as previously reported [8,9]. 3,5-dicaffeoylquinic acid was found in all other studied Asterideae subfamily plants but in none of the studied Cichorioideae except $H$. pilosella. HPLC showed chicoric acid is largely predominant in chicory and dandelion, with lesser amounts of chlorogenic acid in the absence of dicaffeoylquinic derivatives. The genus Hieracium (Cichorioideae) is clearly distinguishable from its subfamily as its composition is typical of the Asteridae subfamily [10]. In almost all representatives of the Asteridae subfamily, as well as in the mouse-ear, the principal component is 3,5-dicaffeoyl-quinic acid. In some cases, the major compound is 1,5-dicaffeoylquinic acid, as in $A$. verlotiorum, or chlorogenic acid, as in S. gigantea, but the presence of 1,5-dicaffeoylquinic acid was inconsistent within the species. Most of the 18 species except chicory and dandelion contain 4,5-dicaffeoylquinic acid, but in relatively low proportions. Characteristic HPLC profiles of the caffeoyl derivatives from $H$. pilosella (containing chlorogenic acid, 1,5-, 3,5- and 4,5-dicaffeoylquinic acids) and $T$. officinale (chlorogenic and chicoric acids) are shown in Figure 1.

Table 1 gives quantitative data on polyphenolic compound levels in the 18 Asteraceae herbs. Among individual caffeoyl derivatives, large amounts of chicoric acid were found in C. intybus ((38.67 \pm 1.65$) \mathrm{mg} / \mathrm{kg} \mathrm{DM})$ and $T$. officinale $((34.08 \pm 1.90) \mathrm{mg} / \mathrm{kg} \mathrm{DM})$. Other plants studied generally contain significant amounts of 3,5-dicaffeoylquinic acid, including A. millefolium, A. absinthium, A. vulgaris, E. cannabinum, $H$. pilosella, $S$. virgaurea, and $T$. parthenium which was the richest at approximately 20 to $30 \mathrm{~g} / \mathrm{kg}$. Levels were fairly variable depending on species, ranging from 0.78 to $30.08 \mathrm{~g} / \mathrm{kg}$ with a mean of $(13.27 \pm 9.36) \mathrm{g} / \mathrm{kg}$. High quantities of 1,5-dicaffeoylquinic acid were only found in $A$. verlotiorum, at $34.85 \mathrm{mg} / \mathrm{kg}$. Significant quantities of 20 to $25 \mathrm{~g} / \mathrm{kg}$ of chlorogenic acid were found in A. verlotiorum, $H$. pilosella and S. gigantea, with a main and SD of $(8.07$ $\pm 7.29) \mathrm{g} / \mathrm{kg}$ indicating a high variability among species (0.55 to $25.54 \mathrm{~g} / \mathrm{kg}$ ). In the Asteridae herbs and $H$. pilosella, 4,5-dicaffeoylquinic acid was found in only minor amounts, i.e. 0.80 to $6.05 \mathrm{~g} / \mathrm{kg}$ with a mean of $(2.59 \pm 1.90) \mathrm{g} / \mathrm{kg}$, with $C$. canadensis having the highest content. For the 18 Asteraceae species, overall rates calculated by summing individual caffeoyl derivative levels determined by HPLC (T1 in Table 1) ranged from $1.33 \mathrm{~g} / \mathrm{kg}$ for C. officinalis to $62.85 \mathrm{~g} / \mathrm{kg}$ for $H$. pilosella, with an average value of $(32.18 \pm 15.80) \mathrm{g} / \mathrm{kg}$. A few species were poor in these constituents as $C$. recutita, about $5 \mathrm{~g} / \mathrm{kg}$, while most are much richer as $A$. verlotiorum
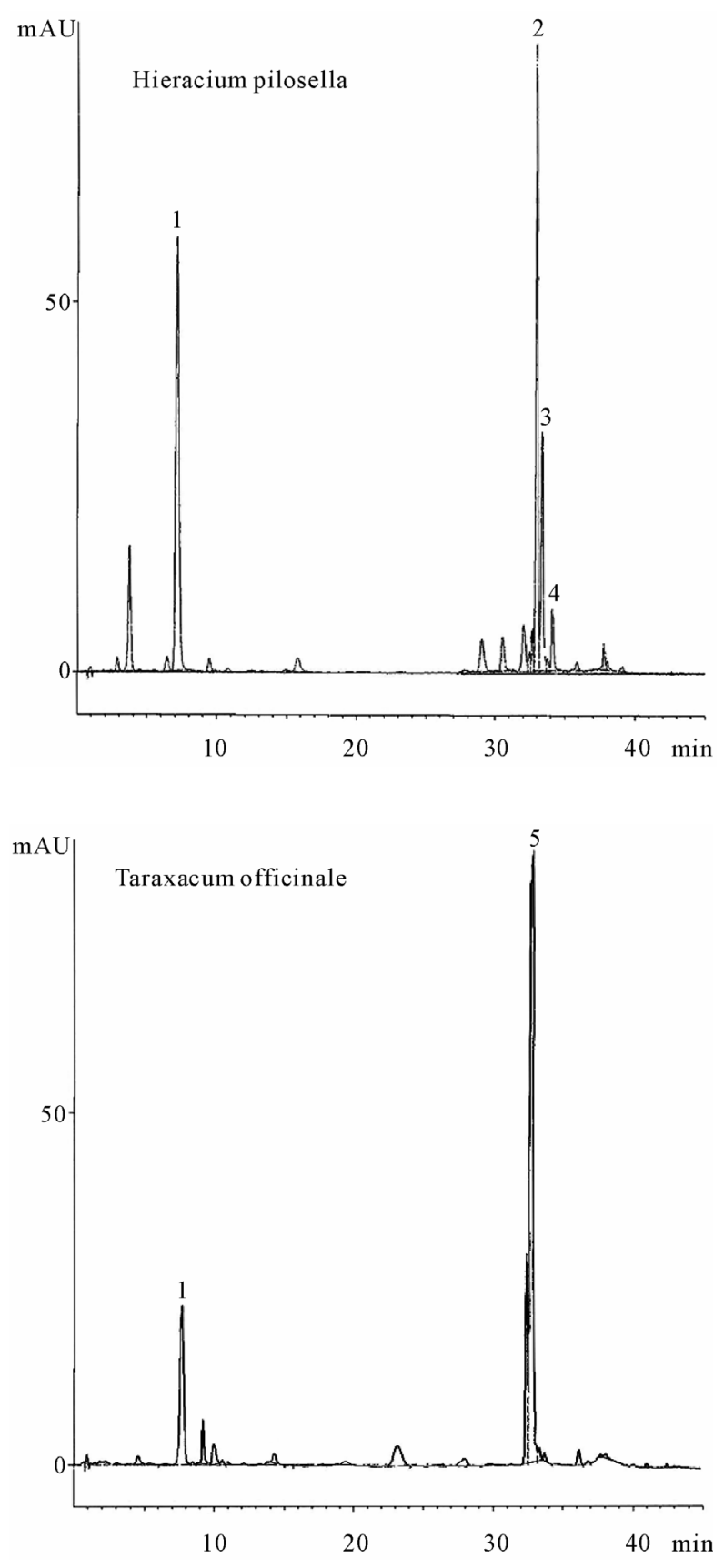

Figure 1. HPLC profiles of caffeoyl derivatives in Hieracium pilosella and in Taraxacum officinale. Peaks: (1) Chlorogenic acid, (2) 3,5-Dicaffeoylquinic acid, (3) 1,5-Dicaffeoylquinic acid, (4) 4,5-Dicaffeoylquinic acid, (5) Chicoric acid. 
Table 1. Polyphenolic compound levels of the 18 Asteraceae herbs (g/kg on dry matter).

\begin{tabular}{|c|c|c|c|c|c|c|c|c|c|c|}
\hline \multirow[b]{2}{*}{ Taxon } & \multicolumn{10}{|c|}{ Polyphenolic compounds (g/kg DM) } \\
\hline & $\begin{array}{l}\text { Chlorogenic } \\
\text { acid }\end{array}$ & 3,5-DCQA & 1,5-DCQA & 4,5-DCQA & $\begin{array}{l}\text { Chicoric } \\
\text { acid }\end{array}$ & $\mathrm{T} 1$ & $\mathrm{~T} 2$ & $\mathrm{~T} 3$ & $\mathrm{~T} 4$ & $\mathrm{~T} 5$ \\
\hline $\begin{array}{l}\text { Achillea } \\
\text { millefolium }\end{array}$ & $8.12 \pm 0.40$ & $21.59 \pm 1.08$ & $8.88 \pm 0.44$ & $3.31 \pm 0.22$ & ND & 41.90 & $52.67 \pm 2.90$ & $12.92 \pm 0.68$ & 65.59 & $63.06 \pm 3.16$ \\
\hline $\begin{array}{l}\text { Arnica } \\
\text { montana }\end{array}$ & $3.63 \pm 0.18$ & $7.52 \pm 0.37$ & $11.80 \pm 0.59$ & ND & ND & 22.95 & $39.32 \pm 2.01$ & $8.12 \pm 0.42$ & 47.44 & $57.26 \pm 2.79$ \\
\hline $\begin{array}{l}\text { Artemisia } \\
\text { absinthium }\end{array}$ & $6.37 \pm 0.31$ & $22.14 \pm 1.11$ & $2.41 \pm 0.12$ & $3.02 \pm 0.17$ & ND & 33.94 & $43.41 \pm 2.16$ & $4.62 \pm 0.22$ & 48.03 & $57.22 \pm 2.73$ \\
\hline $\begin{array}{c}\text { Artemisia } \\
\text { verlotiorum }\end{array}$ & $19.44 \pm 0.97$ & $5.43 \pm 0.41$ & $34.85 \pm 1.57$ & $0.80 \pm 0.11$ & ND & 60.52 & $67.78 \pm 3.87$ & $2.43 \pm 0.17$ & 70.21 & $72.51 \pm 4.07$ \\
\hline $\begin{array}{c}\text { Artemisia } \\
\text { vulgaris }\end{array}$ & $4.51 \pm 0.22$ & $18.89 \pm 0.94$ & $4.67 \pm 0.23$ & $4.04 \pm 0.28$ & ND & 32.11 & $52.33 \pm 2.55$ & $2.07 \pm 0.12$ & 54.40 & $62.27 \pm 2.97$ \\
\hline $\begin{array}{c}\text { Calendula } \\
\text { officinalis }\end{array}$ & $0.55 \pm 0.02$ & $0.78 \pm 0.04$ & ND & ND & ND & 1.33 & $7.54 \pm 0.39$ & $5.12 \pm 0.24$ & 12.66 & $24.97 \pm 1.20$ \\
\hline $\begin{array}{c}\text { Chamaemelum } \\
\text { nobile }\end{array}$ & $4.21 \pm 0.21$ & $13.13 \pm 0.65$ & ND & $2.60 \pm 0.19$ & ND & 19.94 & $43.29 \pm 2.27$ & $22.33 \pm 1.11$ & 65.62 & $64.08 \pm 2.94$ \\
\hline $\begin{array}{l}\text { Chamomilla } \\
\text { recutita }\end{array}$ & $1.16 \pm 0.06$ & $2.92 \pm 0.14$ & ND & $1.61 \pm 0.12$ & ND & 5.69 & $15.89 \pm 0.76$ & $9.48 \pm 0.46$ & 25.37 & $36.79 \pm 1.74$ \\
\hline $\begin{array}{l}\text { Cichorium } \\
\text { intybus }\end{array}$ & $3.34 \pm 0.16$ & ND & ND & ND & $38.67 \pm 1.90$ & 42.01 & $61.07 \pm 2.97$ & $5.07 \pm 0.25$ & 66.14 & $63.22 \pm 3.24$ \\
\hline $\begin{array}{l}\text { Conyza } \\
\text { canadensis }\end{array}$ & $5.29 \pm 0.26$ & $14.55 \pm 0.72$ & $1.89 \pm 009$ & $6.05 \pm 0.38$ & ND & 27.78 & $60.05 \pm 2.98$ & $10.34 \pm 0.50$ & 70.39 & $76.41 \pm 3.78$ \\
\hline $\begin{array}{l}\text { Eupatorium } \\
\text { cannabinum }\end{array}$ & $14.67 \pm 0.73$ & $22.74 \pm 1.13$ & ND & $4.23 \pm 0.23$ & ND & 41.64 & $65.72 \pm 3.37$ & $8.10 \pm 0.41$ & 73.82 & $81.47 \pm 3.75$ \\
\hline $\begin{array}{l}\text { Hieracium } \\
\text { pilosella }\end{array}$ & $25.54 \pm 1.27$ & $24.17 \pm 1.21$ & $10.32 \pm 0.49$ & $2.82 \pm 0.16$ & ND & 62.85 & $67.68 \pm 3.41$ & $12.51 \pm 0.60$ & 80.19 & $82.44 \pm 4.44$ \\
\hline $\begin{array}{l}\text { Matricaria } \\
\text { perforata }\end{array}$ & $5.23 \pm 0.26$ & $13.72 \pm 0.68$ & $1.66 \pm 0.86$ & $1.86 \pm 0.15$ & ND & 22.47 & $30.83 \pm 1.62$ & $23.44 \pm 1.13$ & 54.27 & $60.85 \pm 3.11$ \\
\hline $\begin{array}{l}\text { Solidago } \\
\text { gigantea }\end{array}$ & $20.33 \pm 1.01$ & $7.56 \pm 0.38$ & ND & $2.65 \pm 0.21$ & ND & 30.54 & $62.34 \pm 3.10$ & $16.17 \pm 0.79$ & 78.51 & $83.27 \pm 4.42$ \\
\hline $\begin{array}{l}\text { Solidago } \\
\text { virgaurea }\end{array}$ & $11.45 \pm 0.57$ & $21.78 \pm 1.09$ & ND & $4.23 \pm 0.18$ & ND & 37.46 & $57.90 \pm 2.77$ & $6.73 \pm 0.32$ & 64.63 & $73.76 \pm 3.72$ \\
\hline $\begin{array}{l}\text { Tanacetum } \\
\text { parthenium }\end{array}$ & $6.45 \pm 0.32$ & $30.08 \pm 1.49$ & ND & $5.61 \pm 0.27$ & ND & 42.14 & $57.21 \pm 2.81$ & $13.97 \pm 0.70$ & 71.18 & $81.12 \pm 4.29$ \\
\hline $\begin{array}{l}\text { Tanacetum } \\
\text { vulgare }\end{array}$ & $4.12 \pm 0.21$ & $11.83 \pm 0.59$ & ND & $3.54 \pm 0.20$ & ND & 19.49 & $41.53 \pm 2.07$ & $11.40 \pm 0.59$ & 52.93 & $65.86 \pm 3.17$ \\
\hline $\begin{array}{l}\text { Taraxacum } \\
\text { officinale }\end{array}$ & $0.84 \pm 0.04$ & ND & ND & ND & $34.08 \pm 1.65$ & 34.92 & $53.92 \pm 2.80$ & $1.62 \pm 0.08$ & 55.54 & $53.59 \pm 2.47$ \\
\hline
\end{tabular}

(DCQA) Dicaffeoylquinic acid, (T1) Total caffeoyl derivatives (determined by HPLC), (T2) Total dihydroxycinnamic derivatives (determined by colorimetry), (T3) Total flavonoids (colorimetry), (T4) Total dihydoxycinnamic derivatives + Total flavonoids (calculated by summing), (T5) Total polyphenolic compounds (colorimetry). Data are mean \pm SD of triplicate analysis. ND, not determined.

about $60 \mathrm{~g} / \mathrm{kg}$, A. millefolium, C. intybus, E cannabinum. and $T$. parthenium, all about $40 \mathrm{~g} / \mathrm{kg}$. The HPLC results on total caffeoyl derivatives can be usefully compared with the results obtained by colorimetry with Arnow's reagent for total dihydroxycinnamic derivatives or total phenolic acids. Colorimetry results (T2 in Table 1) ranged from $7.54 \mathrm{~g} / \mathrm{kg}$ (C. officinalis) to 67.78 for $A$. verlotiorum and $67.68 \mathrm{~g} / \mathrm{kg}$ for $H$. pilosella. Most of the 18 Asteraceae species had very high levels of around 50 to $60 \mathrm{~g} / \mathrm{kg}$, with an average value of $(48.92 \pm 17.11) \mathrm{g} / \mathrm{kg}$.
A good correlation was found between total phenolic acids determined by colorimetry (T2 in Table 1) and the sum (T1 in Table 1) of the caffeoyl derivatives determined individually by HPLC for the 18 herbs $\left(R^{2}=0.8697\right)$ (Figure 2). For comparative purposes, we also determined total flavonoids concentrations of the aerial parts of the 18 Asteraceae using colorimetry with oxaloboric reagent (T3 in Table 1). The values ranged from $1.62 \mathrm{~g} / \mathrm{kg}$ for $T$ officinale to 22.33 and $23.44 \mathrm{~g} / \mathrm{kg}$ for $C$. nobile and $M$. perforata, respectively. Compared to results for phenolic 


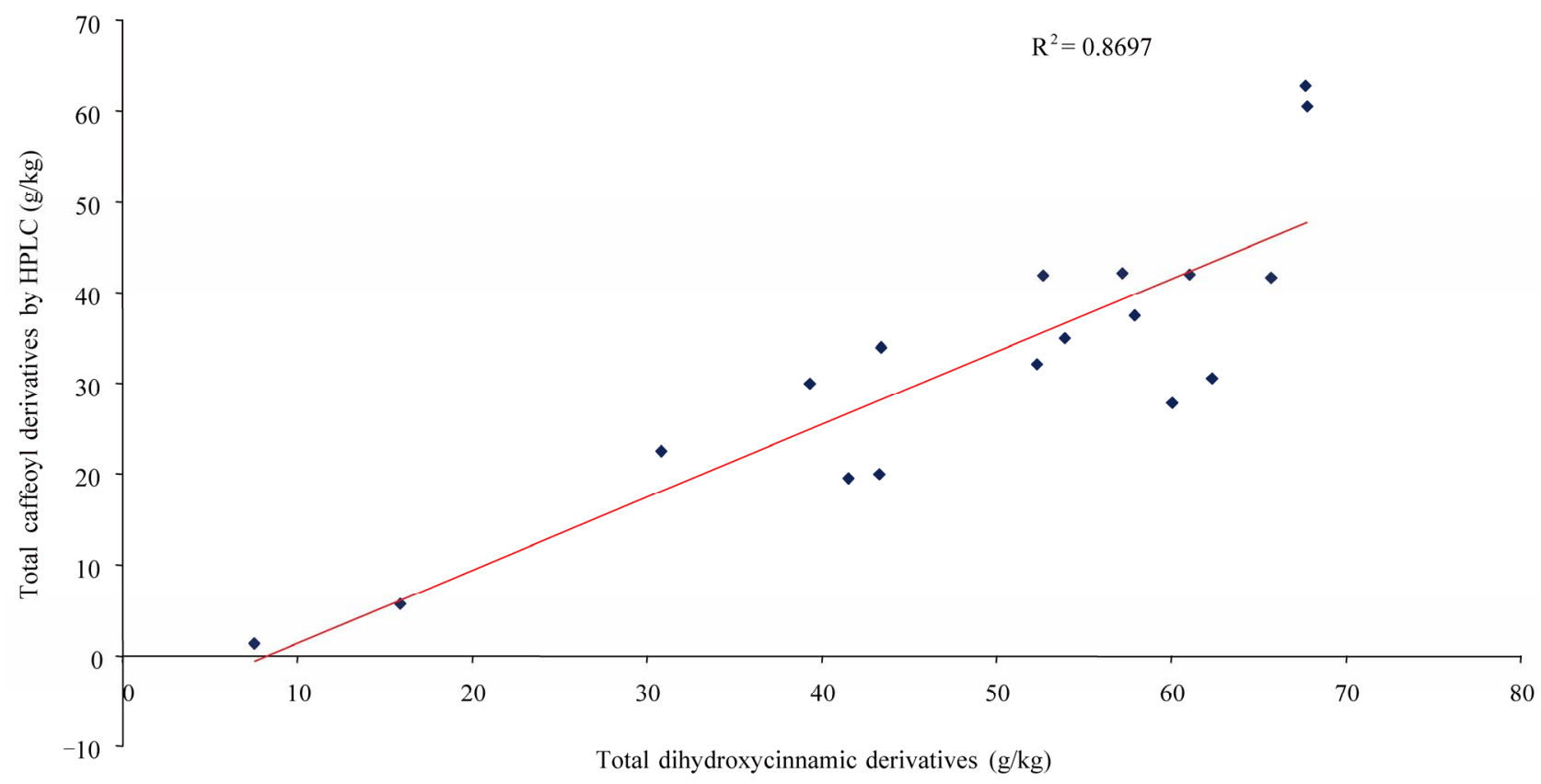

Figure 2. Correlation between total phenolic acids determined by colorimetry (T2 in Table 1) and the sum (T1 in Table 1) of caffeoyl derivatives individually determined by HPLC for the 18 Asteraceae herbs.

acid derivatives, the 18 Asteraceae species showed 3-4-fold higher contents of caffeoyl derivatives than flavonoids. Total polyphenols were also determined by colorimetry with Folin reagent (T5 in Table 1). All taxa contained high quantities of total polyphenolic compounds, from about $25 \mathrm{~g} / \mathrm{kg}$ for $C$. officinalis to more than $80 \mathrm{~g} / \mathrm{kg}$ for E. cannabinum, $H$. pilosella, S. gigantea and T. parthenium, with a mean value of $(64.45 \pm 15.55) \mathrm{g} / \mathrm{kg}$. These values of total polyphenols obtained by direct colorimetry (T5) were compared against those calculated by summing the contents of total dihydoxycinnamic derivatives and total flavonoids ( $\mathrm{T} 4=\mathrm{T} 2+\mathrm{T} 3$ in Table $\mathbf{1})$. The values were comparable, with an average calculated for all 18 species at $(58.72 \pm 17.57) \mathrm{g} / \mathrm{kg}$. We found a very good correlation between total phenolics determined by colorimetry (T5) and the sum (T4) of total phenolic acids and total flavonoids for the 18 Asteraceae herbs $\left(R^{2}=0.9564\right)$ (Figure 3). The presence of other phenolic compounds such as tannins may help explain some differences $[48,49]$. Besides C. officinalis and C. recutita, which were also distinguished by significantly lower levels of total polyphenols, derivatives of phenolic acids and flavonoids represent almost all the polyphenolic compounds for the studied species. As dihydroxycinnamic derivatives are clearly preponderant in relation to flavonoids, these constituents including caffeoyl derivatives can be considered the major phenolic compounds in the studied Asteraceae.

\subsection{Antioxidant Activity of the 18 Compositae Herbs}

Table 2 presents data on the antioxidant activity of the 18 Asteraceae species determined in vitro by DPPH radical scavenging activity. These results are expressed as percentage of total antioxidant capacity for each plant. Species that have the highest antioxidant activities are the richest in polyphenols, while the least active species are less rich in polyphenols, exemplified by C. officinalis and C. recutita at $1.52 \%$ and $2.78 \%$, respectively. The remaining 16 species showed relatively homogeneous activities between $5.08 \%$ to $11.57 \%$, with an average value of $8.37 \% \pm 1.82 \%(7.68 \% \pm 2.65 \%$ for all species $)$. The two most active plants, S. gigantea and H. pilosella, had an absolute antioxidant activity expressed as $\mathrm{EC}_{50}$ of $(44.01 \pm 0.76)$ and $(44.67 \pm 0.81) \mu \mathrm{g} / \mathrm{ml}$, respectively. Such activities are comparable to figures reported in the literature for Asteraceae species $[19,21]$. On the whole, the antioxidant activities of the 18 species compared to their different polyphenolic levels showed good correlations between total phenolics (T5 in Table 1) or total dihydroxycinnamic derivatives (T2 in Table 1) and plant antioxidant capacity, i.e. $R^{2}=0.8904$ (Figure 4) and $R^{2}=$ 0.8529 (Figure 5), respectively, and a relatively good correlation between total caffeoyl derivatives determined by HPLC (T1 in Table 1) and antioxidant activity, at $R^{2}$ $=0.7172$ (Figure 6). Determined individually, the antioxidant activities of chlorogenic acid $\left(\mathrm{EC}_{50}=(13.80 \pm\right.$ 


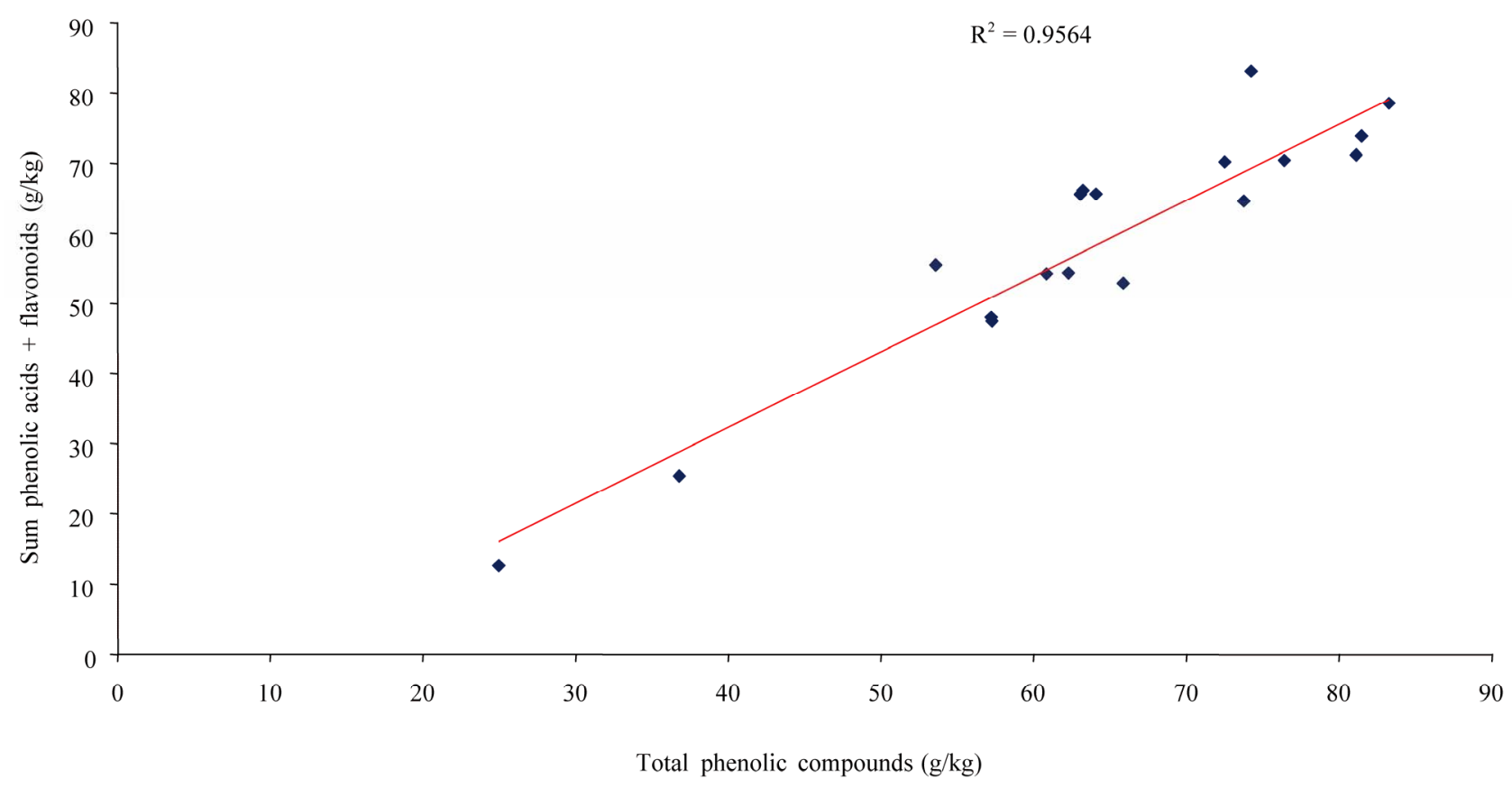

Figure 3. Correlation between total phenolics determined by colorimetry ( T5 in Table 1$)$ and the sum (T4 = T2 + T3 in Table 1) of total phenolic acids (T2) and total flavonoids (T3) for the 18 Asteraceae herbs.

Table 2. Antioxidant capacity (\%) of the 18 Asteraceae herbs and contributions of main caffeoyl derivatives to total antioxidant power.

\begin{tabular}{|c|c|c|c|c|c|c|c|}
\hline \multirow[b]{2}{*}{ Taxon } & \multirow{2}{*}{$\begin{array}{c}\text { Total } \\
\text { capacity }(\%)\end{array}$} & \multicolumn{6}{|c|}{ Contribution of main caffeoyl derivatives to total antioxidant power (\%) } \\
\hline & & $\begin{array}{l}\text { Chlorogenic } \\
\text { Acid }\end{array}$ & $\begin{array}{l}\text { 3,5-Dicaffeoyl } \\
\text {-quinic acid }\end{array}$ & $\begin{array}{l}\text { 1,5-Dicaffeoyl } \\
\text {-quinic acid }\end{array}$ & $\begin{array}{l}\text { 4,5-Dicaffeoyl } \\
\text {-quinic acid }\end{array}$ & $\begin{array}{l}\text { Chicoric } \\
\text { acid }\end{array}$ & $\begin{array}{c}\text { Total caffeoyl } \\
\text { derivatives (sum) }\end{array}$ \\
\hline Achillea millefolium & $8.29 \pm 0.16$ & 10.01 & 33.17 & 13.63 & 4.99 & ND & 61.80 \\
\hline Arnica montana & $5.08 \pm 0.10$ & 7.28 & 18.70 & 29.52 & ND & ND & 55.20 \\
\hline Artemisia absinthium & $6.29 \pm 0.11$ & 10.33 & 45.31 & 4.92 & 6.08 & ND & 66.64 \\
\hline Artemisia verlotiorum & $10.12 \pm 0.15$ & 16.41 & 5.69 & 36.13 & 0.81 & ND & 59.04 \\
\hline Artemisia vulgaris & $7.22 \pm 0.14$ & 6.37 & 33.51 & 8.03 & 7.52 & ND & 55.43 \\
\hline Calendula officinalis & $1.52 \pm 0.02$ & 3.15 & 6.90 & ND & ND & ND & 10.05 \\
\hline Chamaemelum nobile & $9.20 \pm 0.17$ & 4.67 & 18.04 & ND & 3.57 & ND & 26.28 \\
\hline Chamomilla recutita & $2.78 \pm 0.05$ & 4.31 & 13.66 & ND & 7.53 & ND & 25.50 \\
\hline Cichorium intybus & $8.56 \pm 0.18$ & 3.97 & ND & ND & ND & 58.52 & 62.49 \\
\hline Conyza canadensis & $9.63 \pm 0.18$ & 5.71 & 19.52 & 2.49 & 8.19 & ND & 35.91 \\
\hline Eupatorium cannabinum & $7.53 \pm 0.13$ & 19.92 & 38.24 & ND & 7.05 & ND & 65.21 \\
\hline Hieracium pilosella & $11.24 \pm 0.20$ & 23.22 & 27.40 & 11.65 & 3.17 & ND & 65.44 \\
\hline Matricaria perforata & $7.53 \pm 0.14$ & 7.30 & 23.50 & 2.92 & 3.08 & ND & 36.80 \\
\hline Solidago gigantea & $11.57 \pm 0.20$ & 18.15 & 8.38 & ND & 2.86 & ND & 29.39 \\
\hline Solidago virgaurea & $10.04 \pm 0.17$ & 11.75 & 27.68 & ND & 5.31 & ND & 44.74 \\
\hline Tanacetum parthenium & $7.89 \pm 0.15$ & 8.49 & 48.92 & ND & 9.12 & ND & 66.53 \\
\hline Tanacetum vulgare & $7.42 \pm 0.13$ & 5.66 & 19.81 & ND & 5.88 & ND & 31.35 \\
\hline Taraxacum officinale & $6.38 \pm 0.10$ & 1.26 & ND & ND & ND & 68.96 & 70.22 \\
\hline
\end{tabular}

Data are mean \pm SD of triplicate analysis. ND, not determined (compound not determined by HPLC). 


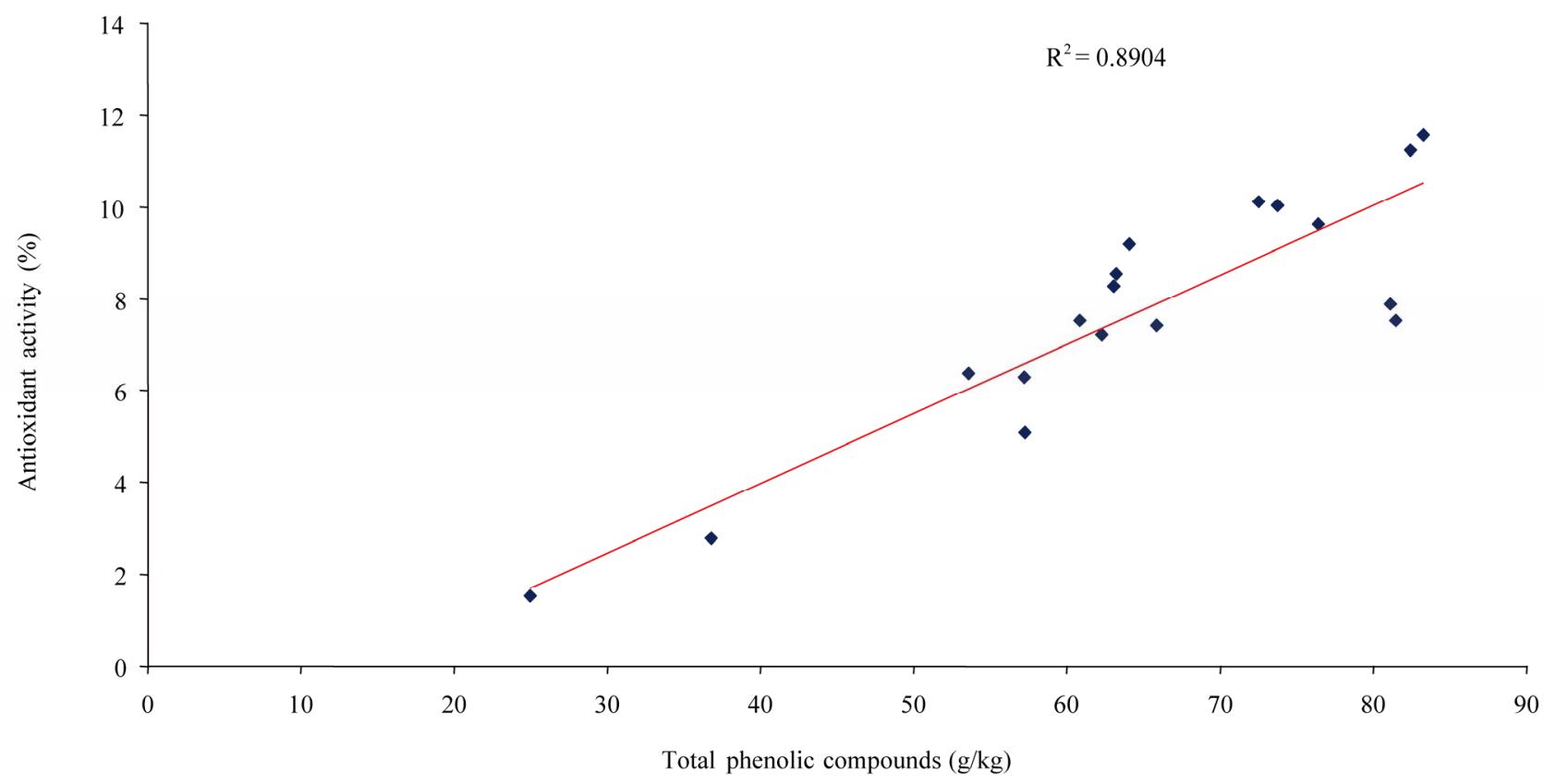

Figure 4. Correlation between total phenolics of the 18 Asteraceae herbs and their antioxidant activity.

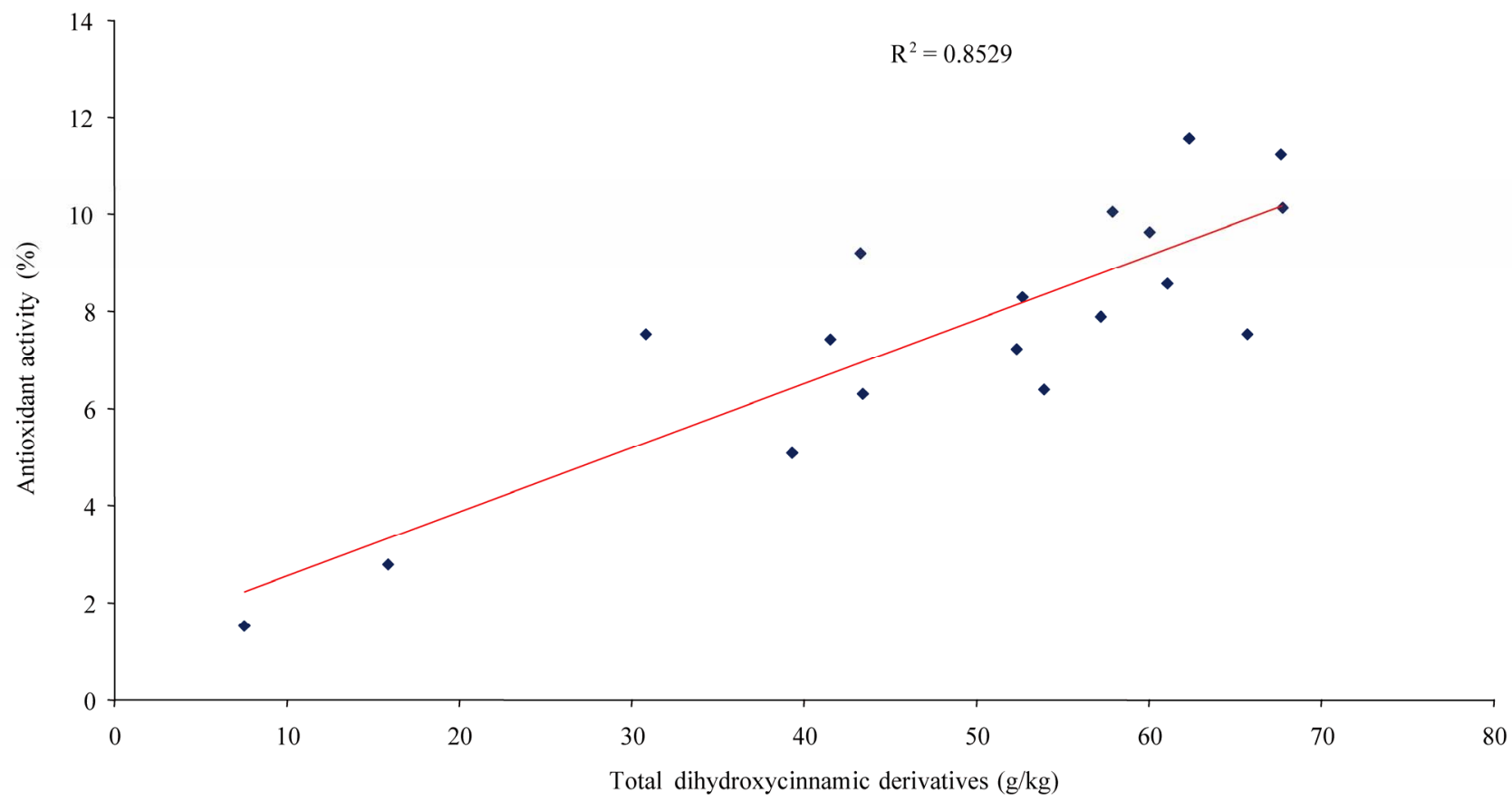

Figure 5. Correlation between total dihydroxycinnamic derivatives (determined by colorimetry) of the 18 Asteraceae herbs and their antioxidant activity.

0.36) $\mu \mathrm{mol} / 1), 3,5$-dicaffeoylquinic acid $\left(\mathrm{EC}_{50}=(7.62 \pm\right.$ $0.22) \mu \mathrm{mol} / \mathrm{l}), 1,5$-dicaffeoylquinic acid $\left(\mathrm{EC}_{50}=(7.85 \pm\right.$ $0.23) \mu \mathrm{mol} / \mathrm{l}), 4,5$-dicaffeoylquinic acid $\left(\mathrm{EC}_{50}=(7.99 \pm\right.$ $0.31) \mu \mathrm{mol} / \mathrm{l})$, and chicoric acid $\left(\mathrm{EC}_{50}=(8.24 \pm 0.27)\right.$ $\mu \mathrm{mol} / \mathrm{l})$ were comparable to those of L-ascorbic acid $\left(\mathrm{EC}_{50}=(15.66 \pm 0.19) \mu \mathrm{mol} / \mathrm{l}\right)$ and quercetin $\left(\mathrm{EC}_{50}=\right.$
$(8.88 \pm 0.21) \mu \mathrm{mol} / \mathrm{l})$ and to figures reported in the literature [19,50].

As caffeoyl derivatives were generally the major phenolic compounds of the studied Asteraceae, we investigated their contributions to the total antioxidant capacity of each plant. Individual and overall values for the 


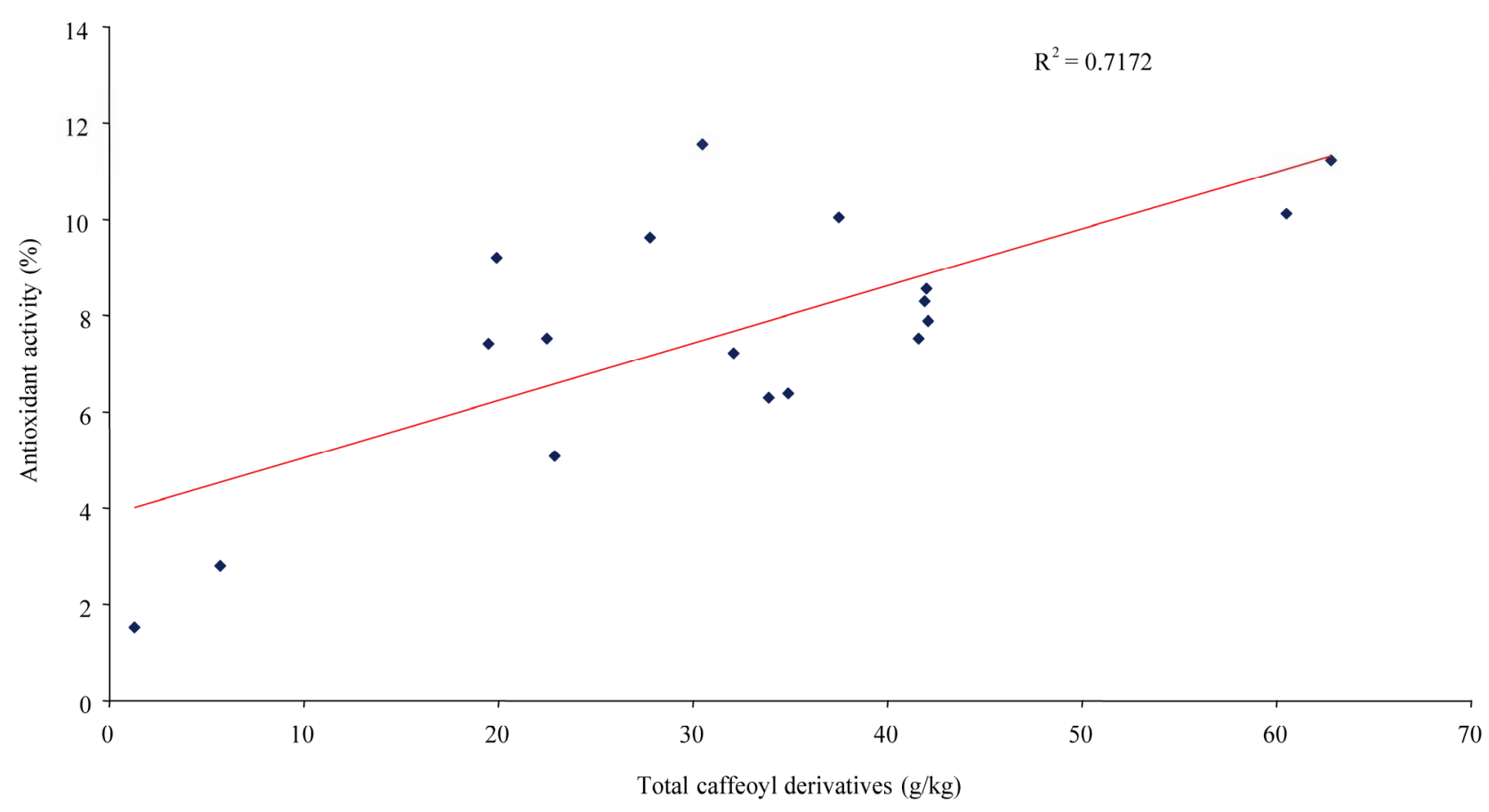

Figure 6. Correlation between total caffeoyl derivatives (determined by HPLC) of the 18 Asteraceae herbs and their antioxidant activity.

5 major caffeoyl derivatives are shown in Table 2. Globally, for all 18 species, the mean contributions of chlorogenic acid, 3,5-dicaffeoylquinic acid, 1,5-dicaffeoylquinic acid and 4,5-dicaffeoylquinic acid to antioxidant activity were $9.33 \% \pm 6.25 \%, 21.58 \% \pm 14.56 \%, 6.07 \%$ $\pm 10.68 \%$ and $4.18 \% \pm 3.12 \%$, respectively, varying similarly with the mean levels of these constituents, i.e. $(8.07 \pm 7.29),(13.27 \pm 9.36),(4.25 \pm 8.57)$ and $(2.59 \pm$ 1.90) $\mathrm{g} / \mathrm{kg}$, respectively. Thus, for each species, the major constituents proved to have the largest contributions to antioxidant activity. Chlorogenic acid contributed $18.15 \%$ to the antioxidant activity of $S$. gigantea $((20.33 \pm 1.01) \mathrm{g} / \mathrm{kg}), 3,5$-dicaffeoylquinic acid contributed $48.92 \%$ to the antioxidant activity of $T$. parthenium $((30.08 \pm 1.49) \mathrm{g} / \mathrm{kg})$ and $45.31 \%$ to the antioxidant activity of $A$. absinthium ((22.14 \pm 1.11$) \mathrm{g} / \mathrm{kg})$, and 1,5-dicaffeoylquinic contributed $36.13 \%$ to the antioxidant activity of $A$. verlotiorum $((34.85 \pm 1.57) \mathrm{g} / \mathrm{kg})$. The contribution of the 4,5-dicaffeoylquinic acid in smaller quantities is therefore minor. In contrast, chicoric acid, which was found in large amounts in C. intybus ((38.67 \pm $1.90) \mathrm{g} / \mathrm{kg}$ ) and $T$. officinale $((34.08 \pm 1.65) \mathrm{g} / \mathrm{kg})$ has a very strong contribution, at $58.52 \%$ and $68.96 \%$, respectively. For example, the levels of major caffeoyl derivatives of $H$. pilosella, i.e. chlorogenic acid and 3,5-, 1,5- and 4,5-dicaffeoylquinic acids ((25.54 \pm 1.27), $(24.17 \pm 1.21),(10.32 \pm 0.49)$ and $(2.82 \pm 0.16) \mathrm{g} \mathrm{kg}^{-1}$, respectively) can be insightfully compared to their contributions to total antioxidant activity $(23.22 \%, 27.40 \%$, $11.65 \%$ and $3.17 \%$, respectively). For another typical plant, $C$. intybus, chlorogenic acid and chicoric acid levels were $(3.34 \pm 0.16)$ and $(38.67 \pm 1.90) \mathrm{g} / \mathrm{kg}$ and their contributions to total antioxidant activity were $3.97 \%$ and $58.52 \%$, respectively. For each plant, summing the contribution values for caffeoyl derivatives gives the total contribution of these constituents to antioxidant capacity. The values ranged from $10.05 \%$ for $C$. officinalis to $70.22 \%$ for $T$. officinale with an average for the 18 taxa of $48.22 \% \pm 18.37 \%$. For some species, such as C. nobile, the relatively low antioxidant contribution of caffeoyl derivatives $(26.28 \%$ ) can be explained by the presence of larger quantities of flavonoids such as chamaemeloside [13]. For all 18 studied Asteraceae, caffeoyl derivatives determined by HPLC (T1 in Table 1) averaged about $50 \%$ (mean 32 vs. $64 \mathrm{~g} / \mathrm{kg}$ ) of total phenolics (T5 in Table 1). Their average contribution to the antioxidant activity of these species is also close to $50 \%$. In addition, for 10 of the 18 plants studied, these compounds contributed over $50 \%$, widely. On the other hand, total dihydroxycinnamic derivatives (T2 in Table 1) averaged about $75 \%$ (mean 49 vs. $64 \mathrm{~g} / \mathrm{kg}$ ) of total phenolics (T5 in Table 1). These constituents, comprising the main caffeoyl derivatives, can thus be considered the major antioxidant compounds in the 18 Asteraceae studied. 


\section{Conclusions}

This work has clarified the polyphenolic composition of wild herbs of Asteraceae studied, and has provided the first evidence of the presence of dicaffeoylquinic derivatives in some of these species. Highly active constituents such as chicoric acid or 3,5-dicaffeoylquinic acid which were present in large amounts in most species contribute very significantly to the antioxidant capacity of these medicinal or food plants. We conclude that, ahead of flavonoids, the main caffeoyl derivatives among polyphenols can be considered the major antioxidant compounds in the aerial parts of studied Asteraceae. The search for such active compounds could be extended to many other medicinal or food plants of the broad Asteraceae family.

\section{Acknowledgements}

We thank Andrée CARNAT (ADPM, University of Auvergne, Clermont-Ferrand, France) who initiated this work.

\section{REFERENCES}

[1] C. A. Rice-Evans, N. J. Miller, P. G. Bolwell, P. M. Bramley and J. B. Pridham, "The Relative Antioxidant Activities of Plant-Derived Polyphenolic Flavonoids," Free Radical Research, Vol. 22, No. 4, 1995, pp. 375-383. doi:10.3109/10715769509145649

[2] T. Okuda, "Antioxidants in Herbs: Polyphenols," In: L. Packer, M. Hiramatsu and T. Yoshikawa, Ed., Antioxidant Food Supplements in Human Health, Academic Press, San Diego, 1999, pp. 393-410. doi:10.1016/B978-012543590-1/50027-5

[3] B. H. Havsteen, "The Biochemistry and Medical Significance of the Flavonoids," Pharmacology \& Therapeutics, Vol. 96, No. 2-3, 2002, pp. 67-202. doi:10.1016/S0163-7258(02)00298-X

[4] V. A. Bandyukova and N. V. Sergeeva, "Polyphenol Compounds in Several Plants of the Family Compositae," Aktual'nye Voprosy Farmatsii, No. 2, 1974, pp. 79-81.

[5] D. Guedon, P. Abbe and J. L. Lamaison, "Leaf and Flower Head Flavonoids of Achillea Millefolium L. Subspecies," Biochemical Systematics and Ecology, Vol. 21, No. 5, 1993, pp. 607-611.

doi:10.1016/0305-1978(93)90060-5

[6] L. Panizzi and M. L. Scarpati, "Constitution of Cynarine, the Active Principle of the Artichoke," Nature, Vol. 174, No. 4440, 1954, p. 1062. doi:10.1038/1741062a0

[7] M. L. Scarpati and G. Oriente, "Chicoric Acid (Dicaffeyltartaric Acid): Its Isolation from Chicory (Chicorium Intybus) and Synthesis," Tetrahedron, Vol. 4, No. 1-2, 1958, pp. 43-48. doi:10.1016/0040-4020(58)88005-9

[8] M. Innocenti, S. Gallori, C. Giaccherini, F. Ieri, F. F. Vincieri and N. Mulinacci, "Evaluation of the Phenolic Content in the Aerial Parts of Different Varieties of
Cichorium Intybus L.," Journal of Agricultural and Food Chemistry, Vol. 53, No. 16, 2005, pp. 6497-6502. doi:10.1021/jf050541d

[9] C. A. Williams, F. Goldstone and J. Greenham, "Flavonoids, Cinnamic Acids and Coumarins from the Different tissues and Medicinal Preparations of Taraxacum Officenale," Phytochemistry, Vol. 42, No. 1, 1996, pp.121-127. doi:10.1016/0031-9422(95)00865-9

[10] C. Zidorn, G. Gottschlich and H. Stuppner, "Chemosystematic Investigations on Phenolics from Flowerheads of Central European Taxa of Hieracium Sensu Lato (Asteraceae)," Plant Systematics and Evolution, Vol. 231, No. 1-4, 2002, pp. 39-58. doi:10.1007/s006060200010

[11] M. Ganzera M. C. Egger, C. Zidorn and H. Stuppner, "Quantitative Analysis of Flavonoids and Phenolic Acids in Arnica montana L. by Micellar Electrokinetic Capillary Chromatography," Analytica Chimica Acta, Vol. 614 No. 2, 2008, pp.196-200. doi:10.1016/j.aca.2008.03.023

[12] L. Z. Lin and J. M. Harnly, "Identification of Hydroxylcinnamoylquinic Acids of Arnica Flowers and Burdock Roots Using a Standardized LC-DAD-ESI/MS Profiling Method," Journal of Agricultural and Food Chemistry, Vol. 56, No. 21, 2008, pp. 10105-10114. doi: $10.1021 / \mathrm{jf} 802412 \mathrm{~m}$

[13] A. Carnat, A. P. Carnat, D. Fraisse, L. Ricoux and J. L. Lamaison, "The Aromatic and Polyphenolic Composition of Roman Camomile Tea," Fitoterapia, Vol. 75, No. 1, 2004, pp. 32-38. doi:10.1016/j.fitote.2003.07.007

[14] M. Ganzera, M. Guggenberger, H. Stuppner and C. Zidorn, "Altitudinal Variation of Secondary Metabolite Profiles in Flowering Heads of Matricaria chamomilla cv. BONA," Planta Medica, Vol. 74, No. 4, 2008, pp. 453457. doi:10.1055/s-2008-1034326

[15] C. Wu, F. Chen, X. Wang, Y. Wu, M. Dong, G. He, R. D. Galyean, L. He and G. Huang, "Identification of Antioxidant Phenolic Compounds in Feverfew (Tanacetum parthenium) by HPLC-ESI-MS/MS and NMR," Phytochemical Analysis, Vol. 18, No. 5, 2007, pp. 401-410. doi:10.1002/pca.995

[16] A. Nugroho, K. H. Kim, K. R. Lee, M. B. Alam, J. S. Choi, W. B. Kim and H. J. Park, "Qualitative and Quantitative Determination of the Caffeoylquinic Acids on the Korean Mountainous Vegetables Used for Chwinamul and Their Peroxynitrite-Scavenging Effect," Archives of Pharmacal Research, Vol. 32, No. 10, 2009, pp. 13611367. doi:10.1007/s12272-009-2003-6

[17] D. Fraisse, A. Carnat, D. Viala, P. Pradel, J. M. Besle, J. B. Coulon, C. Felgines and J. L. Lamaison, "Polyphenolic Composition of a Natural Pasture. Variations Related to the Period of Harvesting," Journal of the Science of Food and Agriculture, Vol. 87, No. 13, 2007, pp. 2427-2435. doi:10.1002/jsfa.2918

[18] A. Carnat, A. Heitz, D. Fraisse, A. P. Carnat and J. L. Lamaison, "Major Dicaffeoylquinic Acids from Artemisia vulgaris," Fitoterapia, Vol. 71, No. 5, 2000, pp. 587-589. doi:10.1016/S0367-326X(00)00163-5 
[19] M. Juan-Badaturuge, S. Habtemariam, C. Jackson and M. J. K. Thomas, "Antioxidant Principles of Tanacetum Vulgare L. Aerial Parts," Natural Product Communications, Vol. 4, No. 11, 2009, pp. 1561-1564.

[20] V. Yatsyuk, "Antioxidants of Medicinal Plants of the Asteraceae," Farmatsevtichnii Zhurnal (Kiev), No. 5, 1989, pp. 75-76.

[21] V. Koleckar, L. Opletal, E. Brojerova, Z. Rehakova, F. Cervenka, K. Kubikova, K. Kuca, D. Jun, M. Polasek, J. Kunes and L. Jahodar, "Evaluation of Natural Antioxidants of Leuzea Carthamoides as a Result of a Screening Study of 88 Plant Extracts from the European Asteraceae and Cichoriaceae," Journal of Enzyme Inhibition and Medicinal Chemistry, Vol. 23, No. 2, 2008, pp. 218-224. doi:10.1080/14756360701450806

[22] J. H. Woo, S. L. Shin and C. H. Lee, "Antioxidant Effects of Ethanol Extracts from Flower Species of Compositae Plant," Journal of the Korean Society of Food Science and Nutrition, Vol. 39, No. 2, 2010, pp. 159-164. doi:10.3746/jkfn.2010.39.2.159

[23] J. M. Canadanovic-Brunet, S. M. Djilas, G. S. Cetkovic and V. T. Tumbas, "Free-Radical Scavenging Activity of Wormwood (Artemisia absinthium L) Extracts," Journal of the Science of Food and Agriculture, Vol. 85, No. 2, 2005, pp. 265-272. doi:10.1002/jsfa. 1950

[24] A. Temraz and W. H. El-Tantawy, "Characterization of Antioxidant Activity of Extract from Artemisia vulgaris," Pakistan Journal of Pharmaceutical Sciences, Vol. 21, No. 4, 2008, pp. 321-326.

[25] P. B. Lubsandorzhieva, "Antioxidant Activity of Extracts of Calendula Officinalis," Khimiya Rastitel'nogo Syr'ya, No. 4, 2009, pp. 123-126.

[26] G. S. Chakraborthy, "Antioxidant Activity of the Sucesssive Extracts of Calendula officinalis Leaves," Asian Journal of Chemistry, Vol. 21, No. 6, 2009, pp. 49574959.

[27] L. P. Stanojevic, M. Z. Stankovic, V. D. Nikolic and L. B. Nikolic, "Antioxidative and Antimicrobial Activities of Hieracium pilosella L. Extracts," Journal of the Serbian Chemical Society, Vol. 73, No. 5, 2008, pp. 531-540. doi:10.2298/JSC0805531S

[28] M. R. Sazegar, A. Banakar, N. Bahrami, A. Bahrami, M. Baghbani, P. Nematolahi and M. Mottaghi, "The Antioxidant Activity of Chamomile (Matricaria Chamomilla L.) Extract in Sunflower Oil," World Applied Sciences Journal, Vol. 9, No. 8, 2010, pp. 873-878.

[29] H. Demir, L. Acik, E. B. Bali, L. Y. Koc and G. Kaynak, "Antioxidant and Antimicrobial Activities of Solidago virgaurea Extracts," African Journal of Biotechnology, Vol. 8, No. 2, 2009, pp. 274-279.

[30] D. Condrat, M. R. Szabo, F. Crisan and A. X. Lupea, "Antioxidant Activity of Some Phanerogam Plant Extracts," Food Science and Technology Research, Vol. 15, No. 1, 2009, pp. 95-98. doi:10.3136/fstr.15.95

[31] D. Mantle, F. Eddeb and A. T. Pickering, "Comparison of
Relative Antioxidant Activities of British Medicinal Plant Species in Vitro," Journal of Ethnopharmacology, Vol. 72, No. 1-2, 2000, pp. 47-51. doi:10.1016/S0378-8741(00)00199-9

[32] P. Dobias, P. Pavlikova, M. Adam, A. Eisner, B. Benova and K. Ventura, "Comparison of Pressurised Fluid and Ultrasonic Extraction Methods for Analysis of Plant Antioxidants and Their Antioxidant Capacity," Central European Journal of Chemistry, Vol. 8, No. 1, 2010, pp. 87-95. doi:10.2478/s11532-009-0125-9

[33] D. Heimler, L. Isolani, P. Vignolini and A. Romani, "Polyphenol Content and Antiradical Activity of Cichorium intybus L. from Biodynamic and Conventional Farming," Food Chemistry, Vol. 114, No. 3, 2009, pp. 765-770. doi:10.1016/j.foodchem.2008.10.010

[34] L. Stanojevic, M. Stankovic, V. Nikolic, L. Nikolic, D. Ristic, J Canadanovic-Brunet and V. Tumbas, "Antioxidant Activity and Total Phenolic and Flavonoid Contents of Hieracium pilosella L. Extracts," Sensors, Vol. 9, No. 7, 2009, pp. 5702-5714. doi:10.3390/s90705702

[35] U. Oezgen, A. Mavi, Z. Terzi, M. Coskun and A. Yildirim, "Antioxidant Activities and Total Phenolic Compounds Amount of Some Asteraceae Species," Turkish Journal of Pharmaceutical Sciences, Vol. 1, No. 3, 2004, pp. 203216.

[36] S. T. Kristo, K. Ganzler, P. Apati, E. Szoke and A. Kery, "Analysis of Antioxidant Flavonoids from Asteraceae and Moraceae Plants by Capillary Electrophoresis," Chromatographia, Vol. 56, No. 1, 2002, pp. S121-S126. doi:10.1007/BF02494124

[37] A. Wojdylo, J. Oszmianski and R. Czemerys, “Antioxidant Activity and Phenolic Compounds in 32 Selected Herbs," Food Chemistry, Vol. 105, No. 3, 2007, pp. 940949. doi:10.1016/j.foodchem.2007.04.038

[38] M. Kratchanova, P. Denev, M. Ciz, A. Lojek and A. Mihailov, "Evaluation of Antioxidant Activity of Medicinal plants Containing Polyphenol Compounds. Comparison of Two Extraction Systems," Acta Biochimica Polonica, Vol. 57, No. 2, 2010, pp. 229-234.

[39] M. N. Makarova, V. G. Makarov, N. M. Stankevich, S. B. Ermakov and I. A. Yashakina, "Characterization of Antiradical Activity of Extracts from Plant Raw Material and Determination of Content of Tannins and Flavonoids," Rastittel'nye Resursy, Vol. 41, 2005, pp. 106-115.

[40] D. Ivanova, D. Gerova, T. Chervenkov and T. Yankova, "Polyphenols and Antioxidant Capacity of Bulgarian Medicinal Plants," Journal of Ethnopharmacology, Vol. 96, No. 1-2, 2005, pp. 145-150.

doi:10.1016/j.jep.2004.08.033

[41] H. Liu, N. Qiu, H. Ding and R. Yao, "Polyphenols Contents and Antioxidant Capacity of 68 Chinese Herbals Suitable for Medical or Food Uses," Food Research International, Vol. 41, No. 4, 2008, pp. 363-370. doi:10.1016/j.foodres.2007.12.012

[42] T. G. Tutin, V. H. Heywood, N. A. Burges, D. M. Moore, D. H. Valentine, S. M. Walters and D. A. Webb, "Flora 
Europaea," Cambridge University Press, Vol. 6, 19641993.

[43] H. Wagner and S. Bladt, "Plant Drug Analysis: A Thin Layer Chromatographic Atlas," 2nd Edition, Springer, Berlin, 1996.

[44] European Directorate for Quality Medicines, "European Pharmacopeia," 6th Edition, European Directorate for Quality Medicines, Strasbourg, 2008.

[45] V. L. Singleton and J. A. J. Rossi, "Colorimetry of Total Phenolics with Phosphomolybdic-Phosphotungstic Acid Reagents," American Journal of Enology and Viticulture, Vol. 16, No. 3, 1965, pp. 144-158.

[46] J. L. Lamaison and C. Petitjean-Freytet, "Principaux Polyphénols et Activités Antioxydantes de Geranium robertianum L.," Pharmaceutica Acta Helvetiae, Vol. 67, No. 12 (Supplement), 1992, pp. 52-56.

[47] C. Nicolle, A. Carnat, D. Fraisse, J. L. Lamaison, E. Rock,
H. Michel, P. Amouroux and C. Remesy, "Characterisation and Variation of Antioxidant Micronutrients in Lettuce (Lactuca sativa Folium)," Journal of the Science of Food and Agriculture, Vol. 84, No. 15, 2004, pp. 2061-2069. doi:10.1002/jsfa.1916

[48] I. Dedio, "Value of Calendula officinalis L. Inflorescences as a Tannin Source," Herba Polonica, Vol. 29, No. 3-4, 1983, pp. 211-216.

[49] O. Kostecka-Madalska and E. Borowczak-Niemczewska, "Tannins in Erigeron Canadensis," Acta Societatis Botanicorum Poloniae, Vol. 37, 1968, pp. 657-664.

[50] H. J. Kim, E. J. Kim, S. H. Seo, C. G. Shin, C. Jin and Y. S. Lee, "Vanillic Acid Glycoside and Quinic Acid Derivatives from Gardeniae," Journal of Natural Products, Vol. 69, No. 4, 2006, pp. 600-603. doi:10.1021/np050447r 